\title{
E-waste in Mexico: a case study of Tepic, Nayarit
}

\author{
C. E. Saldaña ${ }^{1}$, S. Messina ${ }^{1}$, Y. Rodriguez-Lascano ${ }^{1}$, \\ M. García ${ }^{2}$ \& H. Ulloa ${ }^{2}$ \\ ${ }^{1}$ Autonomous University, of Nayarit, Mexico \\ ${ }^{2}$ University of Guadalajara, Mexico
}

\begin{abstract}
In Mexico, in the past 30 years, urban solid waste has become a serious problem of environmental pollution and a cross cutting issue. In this sense, the lifestyles of modern societies lead to primary consumer dynamics of various technologies, which include electronic equipment. Once their useful life is finished, they become waste that ends up in open dumps. Likewise, as they are mainly composed of metals, various substances harmful to health and producing toxic gas emission to soil, water, air substances, waste then generate environmental and public health problems that may be of great magnitude that deteriorate both local and regional surroundings. This research study focuses on the evaluation of an e-waste selective collection program called "Reciclatron" that has been developed at higher education, as a case study at the Autonomous University of Nayarit (UAN), Mexico. The methodology consisted of the classification of e-waste considering the stages of collection, characterization, quantification, recovery and reuse, and marketing $3064.95 \mathrm{~kg}$ of e-waste were collected, projected to exceed 6 tons in the next edition. This program is an opportunity to promote the culture of prevention, environmental awareness and knowledge in the treatment of waste for both the university community and society as a whole.
\end{abstract}

Keywords: e-waste, environmental pollution, Reciclatron, collection.

\section{Introduction}

The technological evolution induced by the highly industrialized countries has generated an extraordinary level of global consumption. Consequently, it has been given more attention and interest in the analysis of environmental problems 
associated with the rapid growth of urban areas in the world. The state of the environment in some cities in different countries (e.g. Pakistan, China, Nigeria, India, Costa Rica, Peru, Haiti, Nicaragua, and Mexico, among others) is an example of the physical problems associated with the process of their urban development. In this sense, urbanization is attractive because of its close relationship between population growth and living standards. However, this synergy causes a number of multifactorial problems affecting the environment; the amount and characteristics of electronic waste known as "e-waste" are a case in point $[1,2]$. This occurs because the current society accelerates the frequency of replacement of electrical and electronic equipment in order to facilitate their daily activities [3].

Latin American countries adopted the technology of developed countries by ignoring the high initial investment, quality, origin and useful life. This situation helps companies to gain more consumers in a rapidly evolving market. These consumer trends trigger serious economic, social and environmental problems due to the lack of public policies aimed at sound management of e-waste. In this context, social and environmental problems caused by inadequate management of e-waste, must be addressed seriously by all countries; because, electronic waste computer equipment are the main cause of soil pollution in the world, surpassing in just ten years other pollutants that degrade the soil. Mechanisms should be implemented to prevent and mitigate the costs and impacts on the environment and the effects on human health.

Once the electronics equipment has completed its life cycle, they become waste (e-waste), and are kept opencast without any treatment. Note that monitors, keyboards, cable, circuits and drives of computers generate the large volumes of toxic waste. Furthermore, the chips of electronic equipment increase at a rate of 3 to $5 \%$ per year, three times faster than municipal waste. Recent studies on the global e-waste generation reports 41.8 million of tons in 2014 and 50.0 million of tons estimated in 2018. It is assumed that the production of current and future ewaste is at its historical maximum estimate due to growing volumes of electronic equipment in disuse [1,4]. This highlights the multifactorial social problems related to poor management of e-waste.

The lack of mechanisms for collection and containment, and improper handling and management of toxic substances associated with e-waste harm human health and disrupt ecosystems. It is therefore essential to apply chemical physical treatments and a special provision to prevent toxic emissions to the environment. On the other hand, electronic waste contains high value metals like gold, silver, copper, and others that can be recovered and re-used in the production cycle of new technologies. This practice allows electronic waste to be a business and a source of work [5].

\section{E-waste global contexts}

Recent studies estimate that during this decade the developing countries produce twice as much waste as the industrialized countries [6]. Moreover, industrialized countries export e-waste to developing countries under the assumption of 
recycling and reuse of components. This leads to problems of a socioenvironmental nature [7].

The United Nations Organization (UNO) in 2006 reported that the generation of e-waste reached 50 million tons, which can increase by 65.4 million tons in 2017.

Moreover, the United Nations Educational, Scientific and Cultural Organization (UNESCO) recognized that the problem of e-waste raises the responsibility of political actors, businessmen and society. It also notes that environmental education in schools is essential to raise awareness among students and their families to take responsibility for the waste they generate. In this sense, the media can raise consumer awareness towards integrated management of ewaste as an important part of the life cycle. Thus, UNESCO considers the problem of electronic waste as a challenge of information societies and knowledge and promotes initiatives for sustainable management [8].

In Europe most of the electrical and electronic waste is incorporated into municipal waste streams, this means that are disposed of in landfills or incinerated without any treatment. In 1998, the United States of America (US) only recycled $11 \%$ of personal computers and $26 \%$.peripherals.

Asia discharges about 12 million tons of e-waste per year. These residues are integrated into municipal waste, as a result of new consumer habits to acquire more frequently, computers, televisions, audio equipment, and printers, among others [4].

There are agreements on the control of cross-border movements of hazardous wastes and their disposal as ruled in the Basel Convention in 1989 and the Stockholm Convention in 2001. In this context, the flow of e-waste from the US, Canada, Australia, the European Union (EU), Japan and Korea to the Asian countries of China, India and Pakistan is significant. In addition, between 60 and $75 \%$ of e-waste in the EU ends in Asia and Africa for recycling and dismantling. Meanwhile, e-waste in Pakistan is imported from the US, EU, Australia, Saudi Arabia, Kuwait, Singapore and the United Arab Emirates, among others. Similarly, Dubai and Singapore serve as centers of e-waste transfer from the EU and US [1].

Millions of tons in e-waste from developed countries are exported as alleged donations. In this sense, Mexico acts as an electronic landfill to receive electronics from the USA, which is the main waste generator worldwide [4].

\section{E-waste national contexts}

In Mexico, environmental pollution has led damages in people's life quality and its environment. The negative impacts on human health, water, air, and soil pollution are evident. Each region has different characteristics in the use of technologies, sale and production, legal and illegal imports and exports, different management programs for Specific Management for Waste, environmental policies and legislation, among others [3].

The annual average of e -waste generation in Mexico is 350 thousand tons from which only $10 \%$ is recycled, $40 \%$ remains stored in residential homes, offices or 
warehouses and 50\% ends up in officials or uncontrolled landfills. The General Law for the Prevention and Management of Waste [9], lists the e-waste as waste requiring special handling and not as hazardous waste. With this in mind, this regulation delegates each state the responsibility to confine the e-waste through management plans. Furthermore, only 19 out of 32 states have a legislation on waste management. Such states are: Aguascalientes, Baja California, Chiapas, Chihuahua, Federal District, Durango, Guanajuato, Guerrero, Hidalgo, Jalisco, Michoacán, Nuevo León, Puebla, Querétaro, Quintana Roo, Sonora, Tabasco, Tamaulipas and Veracruz [10].

The Environment and Natural Resources office (SEMARNAT) through the National Institute of Ecology and Climate Change (INECC) reported that 257,000 tons of e -waste were generated in 2006, while in 2010 were 300,000 and 358,000 in 2014, which means an annually growth of 5-7\% [11].

International conventions in waste matter require participation of the Federal Attorney for Environmental Protection (PROFEPA) and state laws. In this context, Mexico must regulate cross-border movements of e -waste, as well as, suitable disposal of products containing polybrominated biphenyls (PBBs) and polybrominated diphenyl ethers. From 2010 to 2015, the PROFEPA has verified more than 598 cross-border movements of electronic waste equivalent to 3,028 tons.

In this sense, the Ministry of Environment and Natural Resources through the Official Mexican Standard NOM-161-SEMARNAT-2011 establishes criteria for classifying waste requiring special handling including electronics (section VIII, paragraph A). In addition, NOM 161 contains an appendix that mentions waste subject to a special management plan (Table 2) [12].

Although Mexican regulation for waste final disposal establishes management plans, once electronic products run their life time, they become waste and end up in landfills and controlled sites in open dumps and/or unknown disposal [11]. This practice demonstrates a high level of ignorance about the environmental damage that they cause and, moreover, the economic benefit that could lead the recovery and recycling of materials contained in the e-waste is lost.

\section{E-waste and environmental pollution}

It is estimated that $50 \%$ of the e-waste weight corresponds to metals. Steel, aluminum, copper, lead, mercury and precious metals are the main types. The rest of the materials (plastic and glass) are distributed in similar percentages. The most problematic compounds contained in the e-waste are heavy metals, PVC, brominated flame retardants and PCBs. In fact, the environmental impact of e-waste is mainly due to its toxic contents and their mismanagement, causing damages to the environment. It is mentioned in some studies that through an appropriate treatment between $70-90 \%$ of e-waste could be recycled or reused [4], which represents a benefit.

The role of higher education institutions must be to train professionals in sustainable human development. In response to the problem of inadequate waste management some universities in México have organized collection activities of 
electronic waste, including the University of Guadalajara, the University of Veracruz, the Autonomous University of Baja California and the Autonomous Metropolitan University (UAM). In the particular case of the UAM, during 2013, 2014 and 2015 were collected $95.681 \mathrm{~kg} 146.938 \mathrm{~kg}$ and $198.751 \mathrm{~kg}$ respectively, this increase in collection of e-waste is an indicator of social participation and awareness (SEDEMADF, 2016).

In this paper, we present the results on the program of selective collection of ewaste called "Reciclatron" which has been implemented in the Autonomous University of Nayarit (UAN) - Mexico with the aim of promoting in the university community and society, mechanisms to promote organized cooperation to improve the environment.

\section{Case study: Tepic, Nayarit, México}

The state of Nayarit is located at the central-western region of Mexico. It has an area $27,857 \mathrm{~km}^{2}$ which corresponds to $1.4 \%$ of the country. Its territory is a strip that descends from the Sierra Madre Occidental up to the Pacific Ocean. It includes a coastline of $296 \mathrm{~km}$. Latitudes are $23^{\circ} 05^{\prime}-20^{\circ} 36^{\prime} \mathrm{N}, 103^{\circ} 43^{\prime}-105^{\circ} 46^{\prime} \mathrm{W}$. Nayarit has a population of $1,084,979$ inhabitants. The city of Tepic is located at the central part of the state. Its surface represents $7.25 \%$ of the total area of Nayarit. It has a population of 382,863 inhabitants [14].

Final disposal at the city landfill in Tepic, which includes e-waste, is the controlled open landfill called the Iztete (Figure 1). The lack of controlling mechanisms and plant waste separation, treatment and recycling represents a severe problem of local pollution.

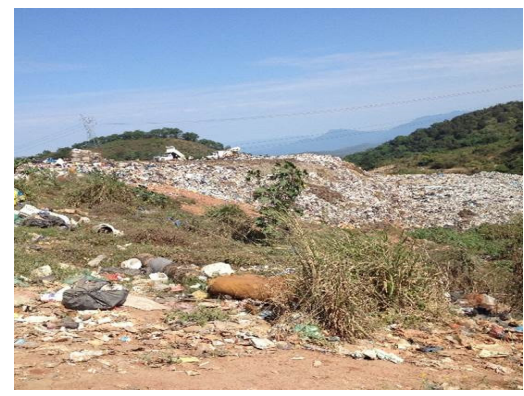

(a)

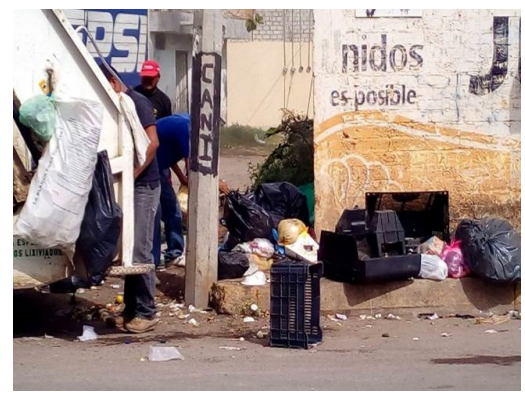

(b)

Figure 1: (a) Lanfill Iztete; (b) MSW collection in Tepic, Nayarit.

\section{Methodology}

The program of selective collection of e-waste implemented at the Autonomous University of Nayarit, called Reciclatrón, has been seen as a good practice and joint collaboration among the university community in caring for the environment in the terms of management of hazardous solid waste and final destination. 
The Reciclatrón consists of a process conformed of five stages: i) collection, ii) characterization, iii) quantification, iv) recovery and reuse, and v) the value chain in the collected e-waste. With the participation of engineering students, the event was organized successfully. The students' participation involved the design of a poster and logo (Figure 2) in order to communicate to society through university media and social networks.

The description of each stage of the process is as follows:

i) Collection. During the days and times established for the completion of Reciclatron, students carried out the collection and weight of electronic equipment. These students were also trained on the proper handling of ewaste and possible environmental and health risks if e-waste was handled inadequately.

ii) Then, the logistics and responsibilities of each student during the collection process were established. As an incentive for college students. This is an 80-hour workshop that is accredited by the University Office of Teaching, and, it is also recognized as an elective course.

iii) Characterization. During this stage the students' collection was classified following the official Mexican regulation: NOM-161-SEMARNAT-2011. Given this fact, a line of mechanical disassembly of the components was installed. Students manually separated components by following the rules of safety and hygiene.

iv) Quantification. After the classification and separation of the components, the separated material was weighed by following the classification presented in Table 2.

v) Recovery and reuse. The components of electronic equipment were separated. Then, they were classified into different purposes for reuse; thus, engineering students could use them in their labs or for prototyping.

vi) In addition to promoting a culture in the management and disposal of e-waste, this represents an economic and environmental benefit.

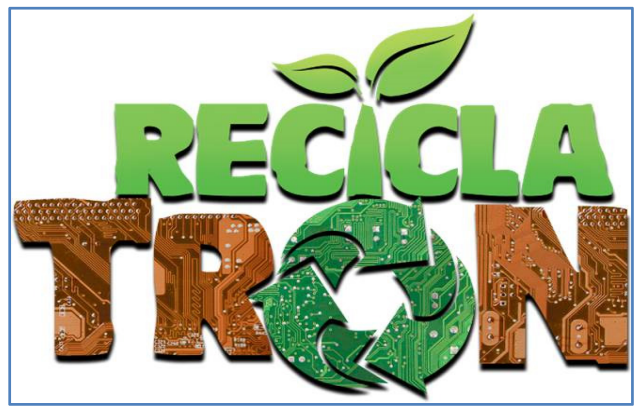

Figure 2: Logo selective collection of e-waste. 


\section{Results analysis}

The amounts of e-waste collected in the two editions of Reciclatrón were treated according to the regulations of the Official Mexican Norm: NOM-161SEMARNAT-2011.

\subsection{Collection}

During this stage, in the first edition $605.87 \mathrm{~kg}$ were collected and in the second edition was $2,459.08 \mathrm{~kg}$. This trend suggests that the next edition will exceed $6,000 \mathrm{~kg}$ (Figure 3).

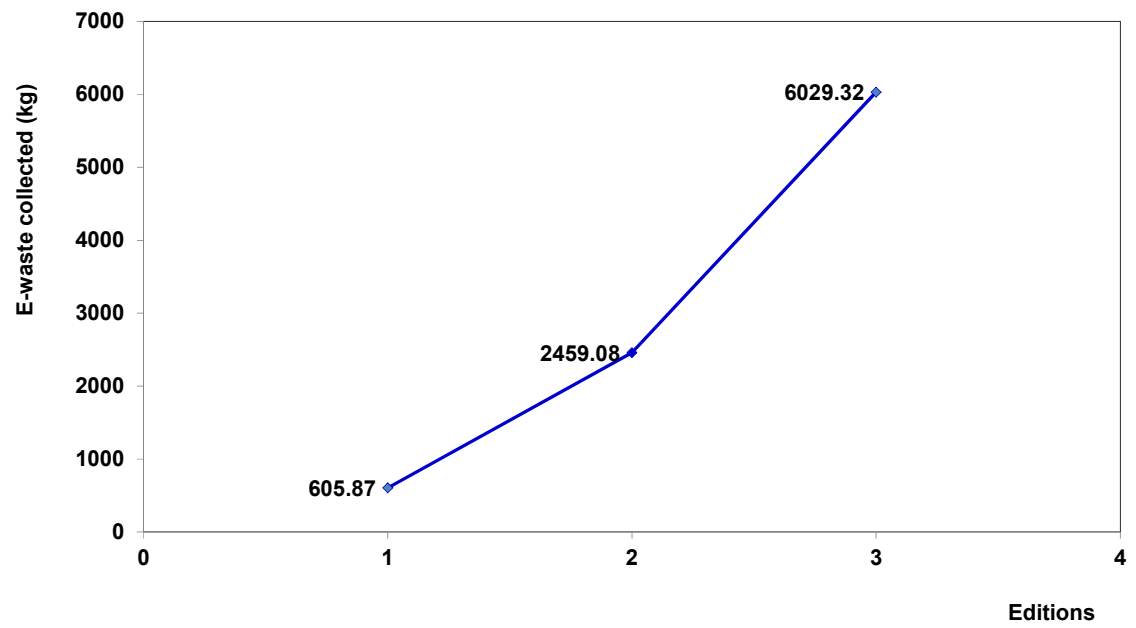

Figure 3: Total collection of e-waste per edition.

\subsection{Characterization}

The characterization was performed with the regulations (NOM-161SEMARNAT-2011) on the Specific Management for Waste, which defines eight types of components of e-waste, as can be observed in Table 1.

A notable aspect was the academic benefit of the student community that participates in the process of disassembly of components. By this practice, students acquired knowledge of the design, architecture, and correlation amongst components, which could translate into the classroom to design new projects or develop innovative prototypes.

\subsection{Quantification}

The quantification of e-waste, was made considering the components of the eight groups defined in the legislation. In the first Reciclatrón, were received $605.87 \mathrm{~kg}$ of e-waste highlighting materials and components of the groups 1, 2, 4 and 8, with a contribution of $339.78 \mathrm{~kg}, 78.72 \mathrm{~kg}, 65.60 \mathrm{~kg}$ and $62.50 \mathrm{~kg}$, representing a $56.08 \%, 13.99 \%, 10.83 \%$ y $10.32 \%$, respectively (as shown in Figure 4). 
Table 1: $\quad$ E-waste identified as classified by the NOM-161-SEMARNAT-2011.

\begin{tabular}{|l|l|}
\hline \multicolumn{1}{|c|}{ Electronic products } & Products found \\
\hline 1.- Personal desktop and accessories & $\begin{array}{l}\text { Computers, laptops, keyboards, } \\
\text { sources, hard drives, regulators, } \\
\text { CD players, printed circuit } \\
\text { boards, floppy disk drives }\end{array}$ \\
\hline 2.- Personal desktop and accessories & Personal desktop, chargers \\
\hline 3.- Cell phones & Cell phones \\
\hline 4.- Monitors with CRTs (including TVs) & Monitors \\
\hline $\begin{array}{l}\text { 5.- Liquid crystal displays and plasma } \\
\text { (including TVs) }\end{array}$ & Screens \\
\hline 6.- Audio players and portable video & $\begin{array}{l}\text { Horns, games, modular, car } \\
\text { stereos, VCRs, recorders, radios, } \\
\text { discman, VHS, nintendos, DVD } \\
\text { player, turntable, horns }\end{array}$ \\
& Cables \\
\hline 7.- Electronic cables & $\begin{array}{l}\text { Printers, scanner, typewriters, } \\
\text { copiers }\end{array}$ \\
\hline 8.- Printers, copiers and multifunctional & \\
\hline
\end{tabular}

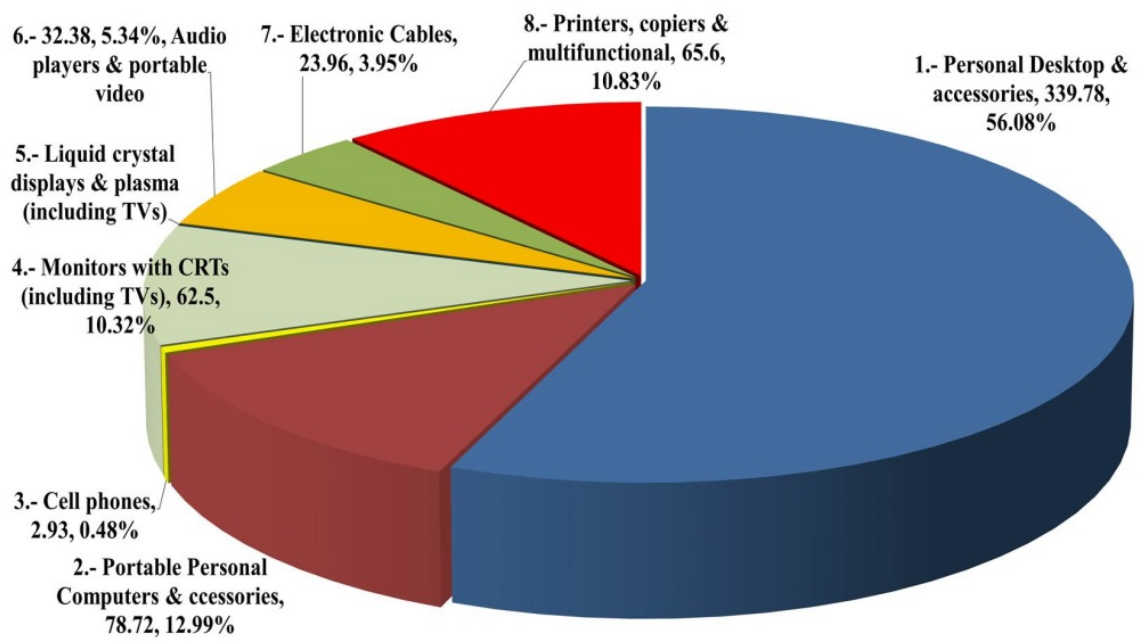

Figure 4: Quantification in kilograms and percentage of Reciclatron, first edition.

In the second edition of Reciclatrón, there were $2,459.08 \mathrm{~kg}$ of e-waste, from which the groups 1, 4, 6 and 8 contributed with $1085.20 \mathrm{~kg}, 722.30 \mathrm{~kg}, 285.25 \mathrm{~kg}$ and $239.37 \mathrm{~kg}$, constituting the $44.13 \%, 29.37 \%, 11.60 \%$, and $9.73 \%$, respectively (as shown in Figure 5). 


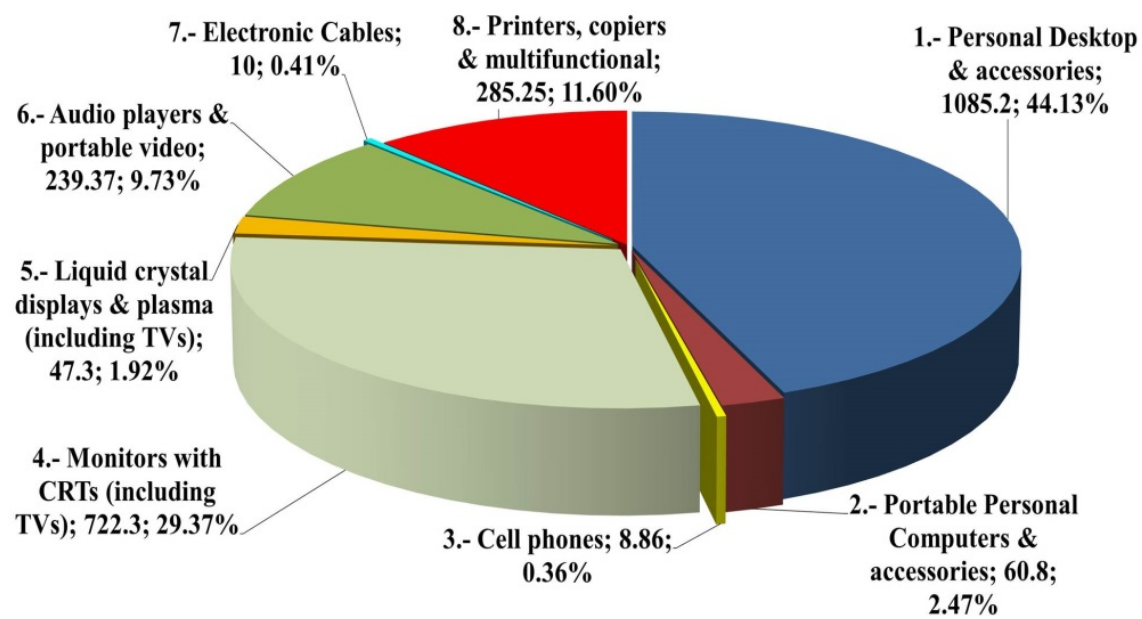

Figure 5: Quantification in kilograms and percentage of Reciclatron, second edition.

\subsection{Recovery and reuse}

Materials such as scrap metal, plastic, keyboards, sheet iron, cables were recovered; metals such as copper and aluminum, primarily; motherboards and hard drives from which scraps, plastic sheets and wires stand out as indicated Figure 6.

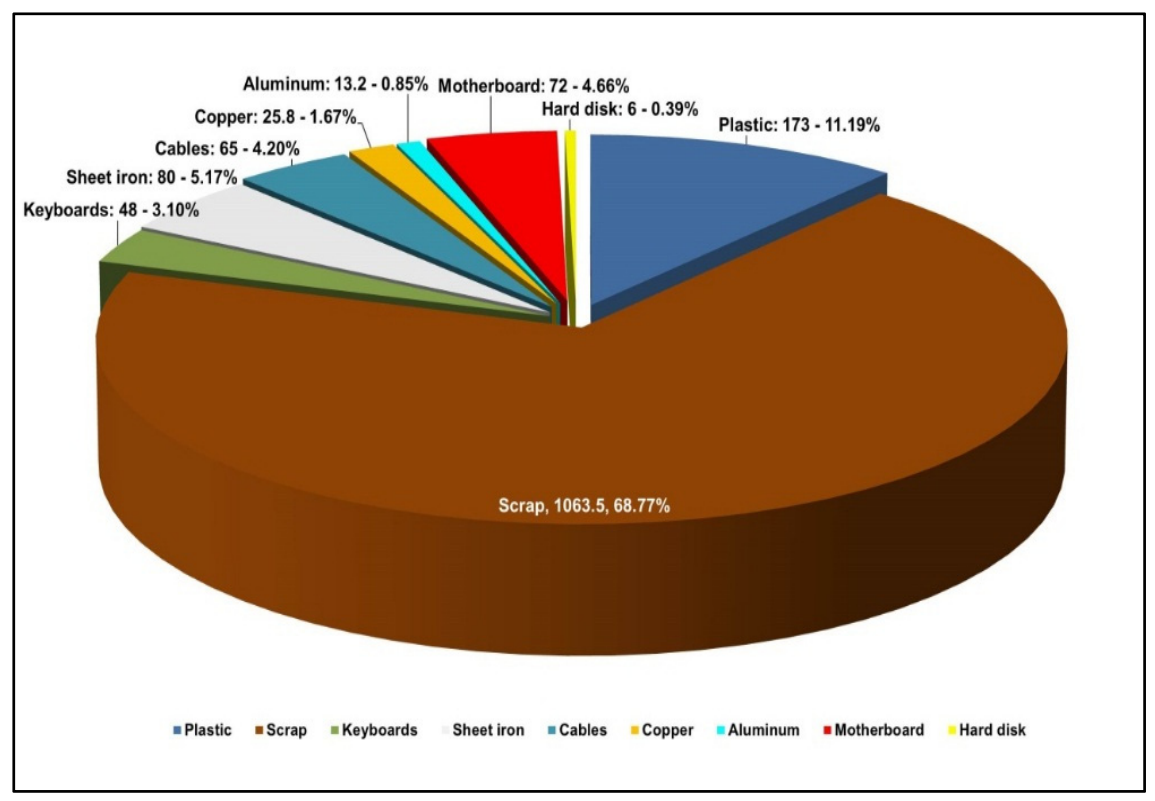

Figure 6: Type of material recovered in kilograms and percentage. 
It is noteworthy that the kilograms of recoverable material obtained in the first edition were $37.98 \mathrm{~kg}$ raising to $1,546 \mathrm{~kg}$ for the second edition. This growth trend suggests that the third edition will achieve in the order of 3,124 kg recoverable for commercialization.

\subsection{Commercialization}

Recoverable e-waste materials were marketed considering their estimated value in the local domestic market. As it can be observed in Table 2, it shows that the greatest economic resources are obtained from motherboards, scrap copper cables.

Table 2: Component recovered and its commercial value.

\begin{tabular}{|l|l|l|l|}
\hline \multicolumn{1}{|c|}{ Material } & \multicolumn{1}{|c|}{$\begin{array}{c}\text { Quantity } \\
\text { commercializad } \\
\text { kilograms }\end{array}$} & $\begin{array}{c}\text { Commercial value } \\
\text { Pesos per } \\
\text { kilograms }\end{array}$ & $\begin{array}{c}\text { Total in pesos } \\
\text { Mexican currency }\end{array}$ \\
\hline Plastic & 173 & 0.50 & 86.50 \\
\hline Scrap & 1063.5 & 2.00 & 2127.00 \\
\hline Keyboards & 48 & 1.00 & 48.00 \\
\hline Sheet iron & 80 & 2.80 & 224.00 \\
\hline Cables & 65 & 25.00 & 1625.00 \\
\hline Cooper & 25.8 & 70.00 & 1806.00 \\
\hline Aluminum & 13.2 & 18.50 & 244.20 \\
\hline Motherboard & 72 & 50.00 & 3600.00 \\
\hline Hard disk & 6 & 5.00 & 30.00 \\
\hline
\end{tabular}

\section{Conclusions}

The Reciclatron is an opportunity for college students and society in Tepic as it represents the implementation of strategies to improve the environment. The collection of e-waste in the two editions summed 3.06495 tons which 6 tons expected to be collected in the next edition. The collection was done in compliance with legislation (NOM-161-SEMARNAT-2011) defining the eight types of components of e-waste classification as it is stated in the Special Waste Management. As a straightforward impact, higher education institutions in Mexico can adopt the methodology shown in this work, to help reduce the impacts of e-waste on the environment. Furthermore, this strategy plan could also provide economic and academic benefits for the parties involved. As for quantification, in the first edition there were more desktop computers than other devices. In second place, there were personal computers, printers, copiers and multifunctional devices, monitors and TVs. In the second edition desktop computers predominated as well as monitors and TVs, printers, copiers, multifunctional and play audio and video. In addition, electronic components can be recovered and reused electronic, 
which have a commercial value. Motherboards, copper and aluminum wires can be of significant revenue in the market. One indicator is that some of the recovered materials have been helpful in developing labs in engineering area. Such programs generate an environmental culture as a link between the society and the students, showing greater involvement and engagement for the care of ecosystems. E-waste recycling, reuse, repair and equipment upgrading are possible strategies that combined can contribute in reducing environmentally harmful materials. Nevertheless, it is commonly expensive to implement such strategies as they require high costs in investment. The management of e-waste is a global priority, therefore, the city of Tepic must develop and implement management plans aimed at electronic waste collection, characterization, quantification, recovery and reuse, as well as the commercialization of the components. Mexico represents an area of opportunity to implement a management model by state, according to the problems and needs in managing e-waste. The linked and coordinated participation of the three levels of government, federal, state and municipal is needed, together with academia, private sector and NGOs to promote in society a culture of sustainability.

\section{References}

[1] Iqbal M., Breivik K., Syed J. H., Malik R. N., Li J., Zhang G., \& Jones K. C. Emerging issue of e-waste in Pakistan: A review of status, research needs and data gaps. Environmetal Pollution, (207), pp. 308-318. 2015.

[2] Martinez C. Gestión y manejo de residuos de aparatos eléctricos y electrónicos (RAEE) en el Perú. IPES Promoción del Desarrollo Sostenible. III Simposio de Residuos Sólidos en el Perú. pp. 52. 2013.

[3] Cárdenas B., Figueroa J. y Fernández E. Método para la caracterización socio-económica de la generación de residuos electrónicos. Revista Iberoamericana de Ciencias. Vol.1, N.6. pp. 131-144. 2014.

[4] Sánchez M., Bonales J., Espinoza R. Contaminación del medio ambiente en la región oriente del estado de Michoacán por desechos electrónicos de equipo de cómputo obsoleto. Mundo Siglo XXI. México. Núm. 13: 61-71. 2008.

[5] Deepali Sinha- Khetriwal, Philipp Kraeuchi, Markus Schwaninger. A coparison of electronic waste recycling in Switzerland and India. Environmental Impact Assessment Review. (25), pp. 492-504. 2005.

[6] Sthiannopkao S. and Wong MH. Handling e-waste in developed and developing countries: Initiatives, practices, and consequences. Science of the Total Environment. (463), pp. 1147-1153. 2013.

[7] Vijay Kumar Garlapati (2015). E-waste in India and developed countries: Management, recycling, business and biotechnological initiatives. Renewable and Sustainable Energy Reviews. (54), pp. 874-881. 2015.

[8] UNESCO. Organización de las Naciones Unidas para la Educación, la Ciencia y la Cultura. Los residuos electrónicos: Un desafio para la Sociedad del Conocimiento en América Latina y el Caribe. Montevideo, Uruguay. p. 261, 2010. 
[9] LGPGIR. Ley General para la Prevención y Gestión Integral de los Residuos. https://www.gob.mx/cms/uploads/attachment/file/27266/Ley_ General_de_Residuos.pdf

[10] Rojas L., Gavilán A., Alcántara V., Cano F. (2012). Los Residuos Electrónicos en México y el Mundo. SEMARNAT-INECC. México, p. 150, 2012.

[11] SEMARNAT-INECC. Diagnóstico básico para la gestión integral de los residuos. Secretaría de Medio Ambiente y Recursos Naturales - Instituto Nacional de Ecología y Cambio Climático. México. 2014.

[12] NORMA Oficial Mexicana NOM-161-SEMARNAT-2011. http://www.profepa.gob.mx/innovaportal/file/6633/1/nom-161-semarnat2011.pdf

[13] SEDEMA CDMX. Secretaría de Medio Ambiente de la Ciudad de México. Reciclatrón: Jornada de acopio de residuos electrónicos y eléctricos. www.sedema.df.gob.mx

[14] Instituto Nacional de Estadística y Geografía. Delimitación de Zonas Metropolitanas de México INEGI. 2010. 